\title{
Bronchial responsiveness to histamine: relationship to diurnal variation of peak flow rate, improvement after bronchodilator, and airway calibre
}

\author{
G RYAN, KM LATIMER, J DOLOVICH, FE HARGREAVE \\ From the Firestone Regional Chest and Allergy Unit, Department of Medicine, St Joseph's Hospital and \\ McMaster University, Hamilton, Ontario, Canada
}

\begin{abstract}
Features of asthma include increases in both bronchial responsiveness and variability of airflow rates. We examined the relationship between bronchial responsiveness to histamine and the variation of peak expiratory flow rate (PFR) during the day and in response to salbutamol $(200 \mu \mathrm{g})$, and the initial $\mathrm{FEV}_{1}$ at the time of the histamine test and $\mathrm{FEV}_{1}$ response to salbutamol. Bronchial responsiveness to histamine was expressed as the provocation concentration causing a fall in $\mathrm{FEV}_{1}$ of $20 \%\left(\mathrm{PC}_{20}\right) . \mathrm{PC}_{20}$ ranged between 13.9 and $130 \mathrm{mg} / \mathrm{ml}$ in nonasthmatic subjects, between 10.5 and $59.9 \mathrm{mg} / \mathrm{ml}$ in five asymptomatic asthmatics, and between 0.03 and $20.8 \mathrm{mg} / \mathrm{ml}$ in 27 asthmatics with symptoms controlled by medication. The lower the $\mathrm{PC}_{20}$ (the greater the bronchial responsiveness) the lower the morning PFR $(r=0.79)$, the greater the increase in PFR after salbutamol (morning $r=-0.75$, evening $r=-0.80$ ), and the greater the difference between the highest and lowest PFR each day $(\mathrm{r}=-0 \cdot 81)$. Measurements of PFR were abnormal, compared with those in nonasthmatic subjects, in all subjects with a $P_{20}$ less than $2 \mathrm{mg} / \mathrm{ml}$-that is, moderate or severe increase in nonspecific bronchial responsiveness-and in none with a $\mathrm{PC}_{20}$ greater than $21 \mathrm{mg} / \mathrm{ml}$ - that is, normal responsiveness; five of nine asthmatics with controlled symptoms had abnormal PFR measurements when $\mathrm{PC}_{20}$ was between 2 and $21 \mathrm{mg} / \mathrm{ml}$-that is, mild hyperresponsiveness. In contrast, $\mathrm{FEV}_{1}$ at the time of the histamine test was greater than $80 \%$ predicted in all subjects with a $\mathrm{PC}_{20}$ greater than $2 \mathrm{mg} / \mathrm{ml}$ and was not less than this in 10 of 18 subjects with a $\mathrm{PC}_{20}$ less than $2 \mathrm{mg} / \mathrm{ml}$. When improvement in $\mathrm{FEV}_{1}$ was $20 \%$ or more after salbutamol, the $\mathrm{PC}_{20}$ was usually moderately or severely increased (less than $0.4 \mathrm{mg} / \mathrm{ml}$ ). The results identify a close relationship between nonspecific bronchial responsiveness to histamine and the variability in flow rates which occurs spontaneously and after bronchodilator. In addition, they raise the possibility that increased airflow obstruction in asthma may be a consequence of increased responsiveness.
\end{abstract}

Scadding ${ }^{1}$ has simplified the definitions of asthma proposed by the Ciba Foundation Guest Symposium $^{2}$ and the Committee on Diagnostic Standards of the American Thoracic Society ${ }^{3}$ to "a disease characterised by a wide variation over a short periods of time in resistance to flow in the airways of the lungs." Increases in resistance to airflow may occur spontaneously as in diurnal variation, may be induced by various nonspecific stimuli which affect asthmatics and by allergens, some industrial chemi-

Address for reprint requests: Dr FE Hargreave, Firestone Regional Chest and Allergy Unit, St Joseph's Hospital, 50 Charlton Avenue East, Hamilton, Ontario, Canada L8N 1 Y4. cals such as isocyanates, and non-steroid antiinflammatory agents which only affect some asthmatics. Airway resistance may be reduced by treatment with drugs such as bronchodilators or corticosteroids.

Confirmation of the presence of asthma is usually made by improvement in $\mathrm{FEV}_{1}$ after bronchodilator, ${ }^{4}$ by measurements of diurnal variation of peak expiratory flow rate (PFR), ${ }^{56}$ and by demonstration of an increase in bronchial responsiveness to nonspecific or allergic or other specific stimuli. ${ }^{7}$ Nonspecific bronchial responsiveness is often measured by inhalation tests with histamine or methacholine, ${ }^{8}$ and this correlates closely with 
responsiveness to other nonspecific stimuli such as exercise ${ }^{9}$ and cold air. ${ }^{10}$

In this study we have examined, in nine nonasthmatic and 32 asthmatic subjects, the relationship between nonspecific bronchial responsiveness to histamine and the diurnal variation of PFR and the response to bronchodilator, the $F E V_{1}$ measured at the time of the histamine test, and the improvement in FEV produced by a bronchodilator.

\section{Methods}

Nine adults regarded as nonasthmatic were recruited from hospital staff (table). None had current or previous episodic dyspnoea, chest tightness, wheezing, or chronic cough. Two were current cigarette smokers and two others were atopic as indicated by one or more wheal and flare responses to prick skin tests with 16 common allergen extracts.

Thirty-two subjects considered to have asthma and no other chest disease were selected from patients attending the Chest and Allergy Clinic (table). All had a history of episodic dyspnoea and wheeze and relief of symptoms by treatment with a bronchodilator. Five had not had symptoms or required medication for six months to 10 years. The remaining 27 asthmatic subjects had current symptoms or were symptom-free on regular medication. Three were current smokers and 21 were atopic.

All 41 subjects were free of respiratory infection or exposure to allergen to which they were sensitised (except for house dust in 16) for four weeks before the study and during the study. Medication used by the 27 asthmatics was inhaled salbutamol less than once daily in nine and daily salbutamol in 18 with additional beclomethasone in 12 and additional prednisone in one. Salbutamol was withheld for at least six hours before measurement of peak expiratory flow rate (PFR) and bronchial responsiveness to histamine or salbutamol. At the time of the study, the initial $\mathrm{FEV}_{1}$ was greater than $86 \%$ predicted in the nonasthmatics and greater than $91 \%$ predicted in the asthmatics without symptoms; in the asthmatics with current symptoms it was greater than $80 \%$ in 19 and $43-78 \%$ in other eight (table).

\section{MEASUREMENT OF BRONCHIAL}

RESPONSIVENESS TO HISTAMINE

An inhalation test with histamine was carried out in each subject between 1200 and $1700 \mathrm{~h}$ using the method described by Cockcroft et al. ${ }^{11}$ First the subjects rested in the laboratory for $\mathbf{3 0} \mathrm{min}$ and then their $\mathrm{FEV}_{1}$ was measured. Then each inhaled an aerosol of saline followed by two-fold increasing concentrations of histamine acid phosphate $(0.03$ $64 \mathrm{mg} / \mathrm{ml}$ ). Aerosols were generated by a Wright nebuliser (airflow rate $7.5 \mathrm{l} / \mathrm{min}$, pressure $50 \mathrm{lb} / \mathrm{in}^{2}$ $(344 \mathrm{kPa})$, output $0.145 \mathrm{ml} / \mathrm{min})$ and inhaled by tidal breathing for $2 \mathrm{~min}$. The response was measured by FEV, $30 \mathrm{~s}$ and $90 \mathrm{~s}$ after each inhalation. Inhalations were discontinued when there was a fall in $\mathrm{FEV}_{1}$ of $20 \%$ or more from the lowest post-saline value. The results were expressed as the concentration of histamine which caused a fall in FEV $\mathrm{Fo}_{1}$ $20 \%\left(\mathrm{PC}_{20}\right)$ and this was obtained from the $\log$ concentration-percent fall in $\mathrm{FEV}_{1}$ curve by linear interpolation of the last two points. Concentrations of greater than $64 \mathrm{mg} / \mathrm{ml}$ were not used because of systemic side effects. If this concentration caused a fall in $\mathrm{FEV}_{1}$ of $15-19 \%$ the $\mathrm{PC}_{20}$ was estimated by extrapolation of the concentration-response curve. Four nonasthmatic subjects were excluded because the fall in $\mathrm{FEV}_{1}$ after this concentration was less than $15 \%$.

\section{MEASUREMENT OF PFR AND RESPONSE TO}

SALBUTAMOL

The subjects measured their PFR with a mini Wright peak flow meter twice daily $(0600-0800 \mathrm{~h}$ and $1600-1800 \mathrm{~h})$ for seven days after the histamine inhalation test. On each occasion the best of three blows was recorded before and $15 \mathrm{~min}$ after inhalation of salbutamol $(200 \mu \mathrm{g})$ from a pressurised cannister. Subjects kept a diary of their symptoms and treatment over this period.

On the day after completion of PFR measurements, at the same time of day as their $\mathrm{PC}_{20}$ was determined, the subjects returned to the laboratory and, after a rest of $30 \mathrm{~min}$, their $\mathrm{FEV}_{1}$ was measured before and $15 \mathrm{~min}$ after inhalation of salbutamol (200 $\mu \mathrm{g})$.

\section{ANALYSIS}

Logarithmic transformation of $\mathrm{PC}_{20}$ was used for all calculations. From the four PFR results each day the percentage increase after bronchodilator morning and evening and diurnal variation of PFR was calculated. Diurnal variation was estimated from both the difference between the two pre-salbutamol results and the difference between the maximum and minimum PFR, and expressed as a percentage of the maximum value. The average of seven days' results was used for analysis. Predicted values for PFR were taken from Cherniack ${ }^{12}$ and for $\mathrm{FEV}_{1}$ from Morris $e$ al. ${ }^{13}$

Linear regression analysis was used to examine the relationship between $\mathrm{PC}_{20}$ and PFR or FEV . If the relationship appeared non-linear, as for the increase in PFR after salbutamol, logarithmic transformation of both PC $_{20}$ and PFR was used. A normal range for increase in PFR and FEV $_{1}$ after salbutamol and for diurnal variation in PFR was taken 
Table Summary of details and results of test measurements in study subjects

\begin{tabular}{|c|c|c|c|}
\hline & \multirow[t]{2}{*}{ Nonasthmatic } & \multicolumn{2}{|l|}{ Asthmatic } \\
\hline & & Past History & Current \\
\hline $\begin{array}{l}\text { Number } \\
\text { Male } \\
\text { Age }(\mathrm{yr}) \\
\text { PC }(\mathrm{mg} / \mathrm{ml}) \\
\text { FEV, initial (\% maximum) } \\
\text { PFR maximum (\% predicted) }\end{array}$ & $\begin{array}{l}9 \\
4 \\
32(25-36)^{*} \\
45(13 \cdot 9-130) \\
94 \cdot 2(4 \cdot 5)^{\dagger} \\
105 \cdot 3(8 \cdot 5) \\
106 \cdot 9(10 \cdot 1)\end{array}$ & $\begin{array}{l}5 \\
4 \\
39(35-52) \\
25 \cdot 6(10 \cdot 4-60) \\
96 \cdot 7(3 \cdot 4) \\
114 \cdot 5(9 \cdot 9) \\
105 \cdot 2(10 \cdot 8)\end{array}$ & $\begin{array}{l}27 \\
14 \\
44(21-67) \\
0 \cdot 87(0 \cdot 03-20 \cdot 8) \\
87 \cdot 5(11 \cdot 7) \\
96 \cdot 6(17 \cdot 5) \\
94 \cdot 5(13 \cdot 7)\end{array}$ \\
\hline $\begin{array}{l}\text { diurnal vanation (\% maximum) } \\
\text { without salbutamol } \\
\text { with salbutamol }\end{array}$ & $\begin{array}{l}2.7(1.7) \\
6.7(2.0)\end{array}$ & $\begin{array}{l}5.0(3.9) \\
8.0(4.0)\end{array}$ & $\begin{array}{r}7.5(5.9) \\
21.9(9.9)\end{array}$ \\
\hline $\begin{array}{l}\text { Response to salbutamol (\% increase) } \\
\text { PFR 0600-0800 } \\
\text { PFR 1600-1800 } \\
\text { FEV }\end{array}$ & $\begin{array}{l}4 \cdot 3(2 \cdot 4) \\
3 \cdot 4(1 \cdot 5) \\
3 \cdot 1(2 \cdot 7)\end{array}$ & $\begin{array}{l}4.5(2.3) \\
3.2(1.4) \\
2.4(1.6)\end{array}$ & $\begin{array}{l}22 \cdot 6(14 \cdot 9) \\
18 \cdot 7(18 \cdot 1) \\
18 \cdot 2(18 \cdot 8)\end{array}$ \\
\hline
\end{tabular}

*mean (range)

tmean (SD)

as the $95 \%$ confidence interval for a single sevenday estimate about the mean of the nine nonasthmatic subjects.

\section{Results}

Bronchial responsiveness to histamine, expressed as $\mathrm{PC}_{20}(\mathrm{mg} / \mathrm{ml})$, ranged between 13.9 and 130 in nonasthmatics, 10.5 and 59.9 in asymptomatic asthmatics, and 0.03 and 20.5 in asthmatics with current symptoms (table).

Bronchial responsiveness in each subject was related to the mean morning and evening PFR (expressed as a percent of maximum), the mean increase in morning and evening PFR after salbutamol, and the diurnal variation in PFR (figs 1-3). Strong correlations were observed between $\mathrm{PC}_{20}$ and PFR, increase in PFR after salbutamol, and diurnal variation using minimum pre-salbutamol and maximum post-salbutamol values. The lower the $\mathrm{PC}_{20}$ (the more increased the bronchial responsiveness) the lower the PFR in the morning $(r=0.82, p<0.001)$ and evening $(r=0.68$, $\mathrm{p}<0.001$ ) (fig 1), the greater the increase in PFR after salbutamol (morning $r=-0.75, p<0.001$; evening $r=-0.80, p<0.001$ ) (fig 2 ), and the greater the variability in PFR during the day $(r=-0.81$, $\mathrm{p}<0.001$ ) (fig 3B). A weaker correlation was observed between $\mathrm{PC}_{20}$ and diurnal variation of PFR using only the pre-salbutamol values $(r=-0.41$, $p<0.01$ ) (fig 3A). Peak flow rate measurements were interpreted as abnormal if they were above the 95\% confidence interval determined from the nonasthmatic subjects (figs 2,3 ). When $P_{20}$ was less than $2 \mathrm{mg} / \mathrm{ml}$ all subjects (asthmatics with current symptoms) had abnormal values, when it was greater than $20.8 \mathrm{mg} / \mathrm{ml}$ the three symptom-free asthmatics had normal values, and when it was be- tween 2 and $20.8 \mathrm{mg} / \mathrm{ml}$ six out of 12 subjects (five of nine asthmatics and one of two symptom-free asthmatics) had abnormal values.

Bronchial responsiveness in each subject was also related to the increase in $\mathrm{FEV}_{1}$ after salbutamol measured one week after but at the same time of day as the histamine test (fig 4). The baseline FEV, was within $15 \%$ of $F E V_{1}$ on the day of the histamine test except in four subjects, higher in two, and lower in two (fig 4). When FEV 1 at the time of the histamine test was expressed as a percent of maximum, it was not abnormal until the $\mathrm{PC}_{20}$ was less than $0.4 \mathrm{mg} /$ $\mathrm{ml}$-that is, it could be normal when bronchial responsiveness was moderately to severely increased (fig 5). When the $\mathrm{FEV}_{1}$ increased by $20 \%$ or more after salbutamol the $\mathrm{PC}_{20}$ was always less than $0.4 \mathrm{mg} / \mathrm{ml}$ - that is, bronchial responsiveness was moderately or severely increased.

\section{Discussion}

The results of this study demonstrate a. strong association between the level of bronchial responsiveness to histamine and the degree of reduction in the morning PFR, the degree of improvement in morning PFR after salbutamol, and the diurnal variation of PFR as measured by the lowest presalbutamol value (usually on waking) and the highest post-salbutamol value (usually in the afternoon). The greater the bronchial responsiveness (the lower the $\mathrm{PC}_{20}$ ) the lower the PFR, the greater the response to salbutamol, and the greater diurnal variation of flow rates. The study covered a wide range of $\mathrm{PC}_{20}$ and included asthmatic subjects with current symptoms, subjects with a past history of asthma, and normal subjects.

All subjects with a $\mathrm{PC}_{20}$ less than $2 \mathrm{mg} / \mathrm{ml}$ had a greater than normal variability of airflow obstruc- 


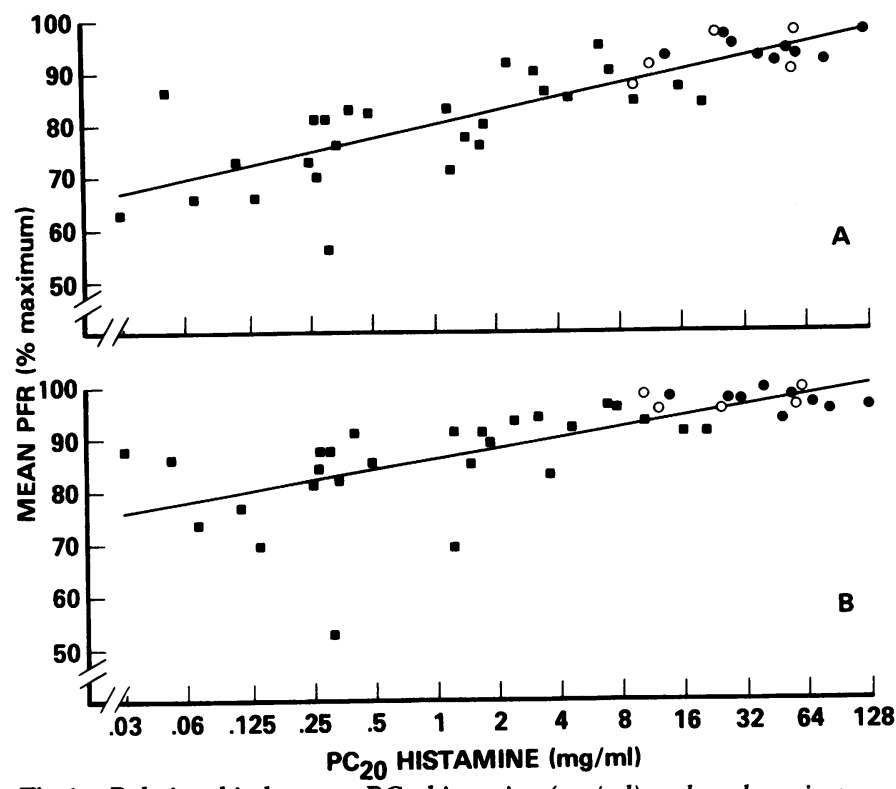

Fig 1 Relationship between $P C_{20}$ histamine $(\mathrm{mg} / \mathrm{ml})$ and peak expiratory flow rate (PFR) measured at 0600-0800h $(A)(r=0.82)$ and $1600-1800 h(B)(r=0.68)$. PFR is the mean of measurements on seven days and is expressed as a percentage of the maximum PFR each day. Forty-one subjects - nine nonasthmatic $(\Theta)$, five previous asthmatic $(O)$, and 27 current asthmatics ( $\square$ ).

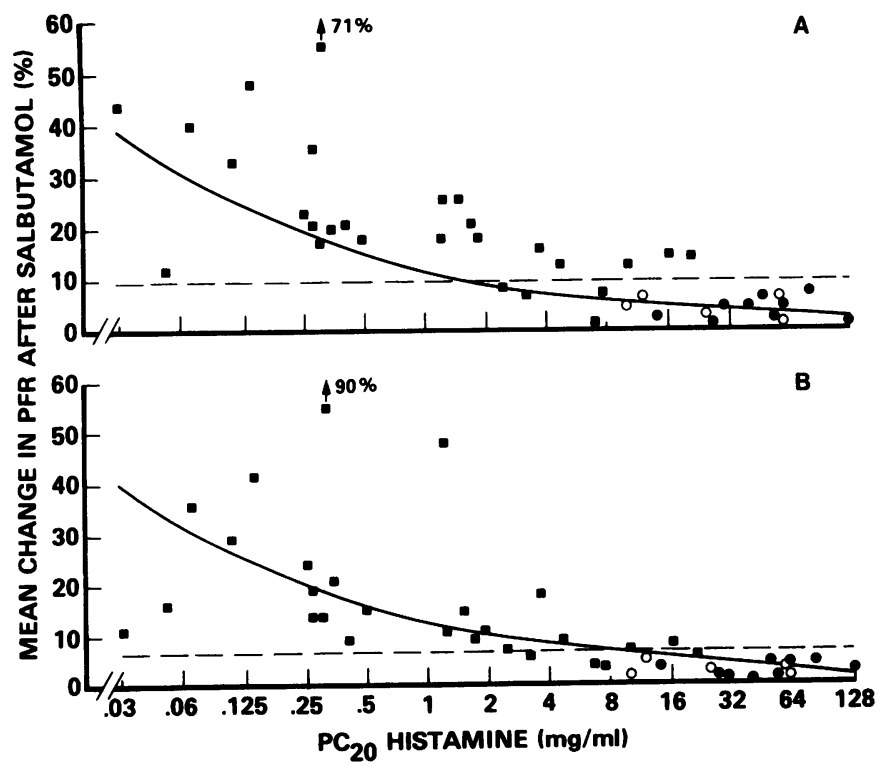

Fig 2 Relationship between $P_{20}$ histamine $(\mathrm{mg} / \mathrm{ml})$ and response to salbutamol $(200 \mu \mathrm{g})$, expressed as percentage increase in PFR.

Response to salbutamol was measured at 0600-0800h $(A)(r=-0.78)$ and 1600-1800h $(B)(r=-0.80)$ for seven days. The horizontal line represents the upper bound of the $95 \%$ confidence interval about the mean of the nonasthmatic subjects; $A, 9.9 \%$ and $B, 6.6 \%$. The curvilinear relationship was obtained by linear regression analysis using logarithmic transformation of both PC 20 and change in PFR. Symbols as in fig 1. 


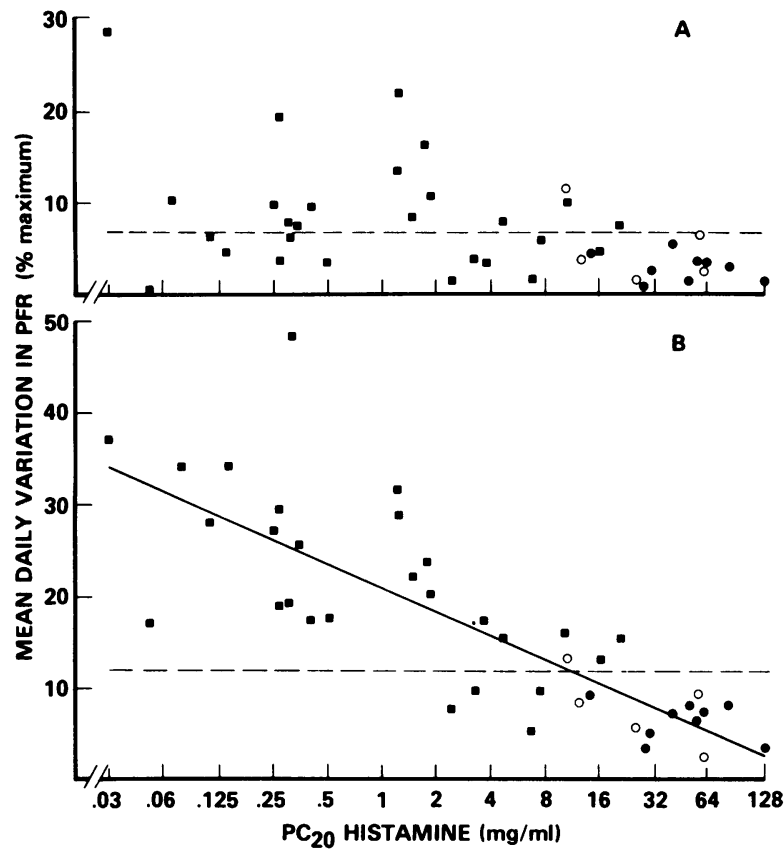

Fig 3 Relationship between $P C_{20}$ histamine $(\mathrm{mg} / \mathrm{ml})$ and variability of PFR during the day. PFR was measured before and after salbutamol at 0600-0800h and 1600-1800h. Variability was calculated by two methods: (A) the difference between the two PFRs before salbutamol and expressed as a percentage of the higher $(r=-0.41)$ and $(B)$ the difference between the maximum and minimum of the four PFR results each day and expressed as a percentage of the maximum ( $r=-0.81)$. The horizontal line represents the upper boundary of the $95 \%$ confidence interval about the mean of the nonasthmatic subjects; $A 6.7 \%$ and $B 11.8 \%$. Symbols as in fig 1 .

tion, as indicated by measurements of diurnal fluctuation of PFR and response to bronchodilator, and were regarded as having asthma with current symptoms. When $\mathrm{PC}_{20}$ was greater than $20 \mathrm{mg} / \mathrm{ml}$ no subject had current symptoms of asthma or any increase in variability of PFR. Three subjects with previous symptoms of asthma had a $\mathrm{PC}_{20}$ above $20 \mathrm{mg} / \mathrm{ml}$; this is to be expected since bronchoconstriction may be incited by a vigorous enough specific reaction stimulated by allergen ${ }^{14}$ or chemical, ${ }^{15}$ and nonspecific responsiveness may be increased so that the $\mathrm{PC}_{20}$ falls below $20 \mathrm{mg} / \mathrm{ml}$ by these ${ }^{1617}$ and other stimuli such as infection..$^{18}$

In subjects with a $\mathrm{PC}_{20}$ from 2 to $20 \mathrm{mg} / \mathrm{ml}$ only about half of those with current symptoms showed increased variability of PFR. Subjects with this mild degree of responsiveness might have a greater perception of asthma ${ }^{17}$ or have symptoms induced by various potent nonspecific stimuli. For example, exercise in warm air may induce bronchoconstric- tion in subjects with a $\mathrm{PC}_{20}$ histamine of up to $4 \mathrm{mg} / \mathrm{ml}^{9}$ and isocapnic hyperventilation of cold dry air may induce bronchoconstriction in subjects with a $\mathrm{PC}_{20}$ of up to $16 \mathrm{mg} / \mathrm{ml} .^{10}$ The observations in the present study are consistent with the findings of Juniper et $a l,{ }^{17}$ who reported that subjects with a $\mathrm{PC}_{20}$ of more than $2 \mathrm{mg} / \mathrm{ml}$ required either no treatment or bronchodilator taken only as required but not daily, indicating that they were not having reductions in flow rate of sufficient severity to cause troublesome symptoms. It is possible for apparently nonasthmatic people to have a $\mathrm{PC}_{20}$ in this range with an increase in variability of flow rates which they have not detected or regarded as abnormal.

The results of our study show that diurnal fluctuation of PFR of more than $12 \%$, response to bronchodilator in the morning of more than $10 \%$, and improvement in $\mathrm{FEV}_{1}$ after bronchodilator of more than $10 \%$ is a greater than normal variation in flow rate and is suggestive of asthma. These results for PFR differ from those recorded by Hetzel and Clarke, who suggested that a diurnal variation of $20 \%$ was a useful screening test for asthma. ${ }^{5}$ However, they studied asthmatics during or shortly after admission to hospital because of severe asthma and milder or more stable asthmatics may not demonstrate this degree of variability. Measurement of $\mathrm{FEV}_{1}$ before and after bronchodilator at a clinic visit or estimation of diurnal variation without use of bronchodilator appeared less sensitive than measurement of diurnal variation recorded before and after bronchodilator. Obviously the usefulness of measurements of variability of flow rates for the diagnosis of asthma needs to be examined formally and compared with the usefulness of measurement of bronchial responsiveness to histamine or methacholine in a larger number of subjects who are carefully characterised by clinical features. ${ }^{21}$

The results also raise the question of the role of bronchial responsiveness in the pathogenesis of asthma; is hyperresponsiveness the primary abnormality in asthma and a prerequisite for the occurrence of airflow obstruction or is it a consequence of reduced airway calibre? ${ }^{22}{ }^{23}$ Our results show that asthmatics may have a moderate or severe increase in responsiveness $\left(\mathrm{PC}_{20}<2.0 \mathrm{mg} / \mathrm{ml}\right)$ at a time when their $\mathrm{FEV}_{1}$ is within $10 \%$ of maximum. Furthermore changes in airway resistance have been observed without changes in responsiveness, ${ }^{24}$ and changes in responsiveness have been observed without changes in resistance. ${ }^{16}$ These observations suggest that other factors are involved in increased responsiveness-for example, there may be an intrinsic abnormality in smooth muscle. In bronchial smooth muscle removed from sensitised and unsensitised dogs baseline tone was the same but the 


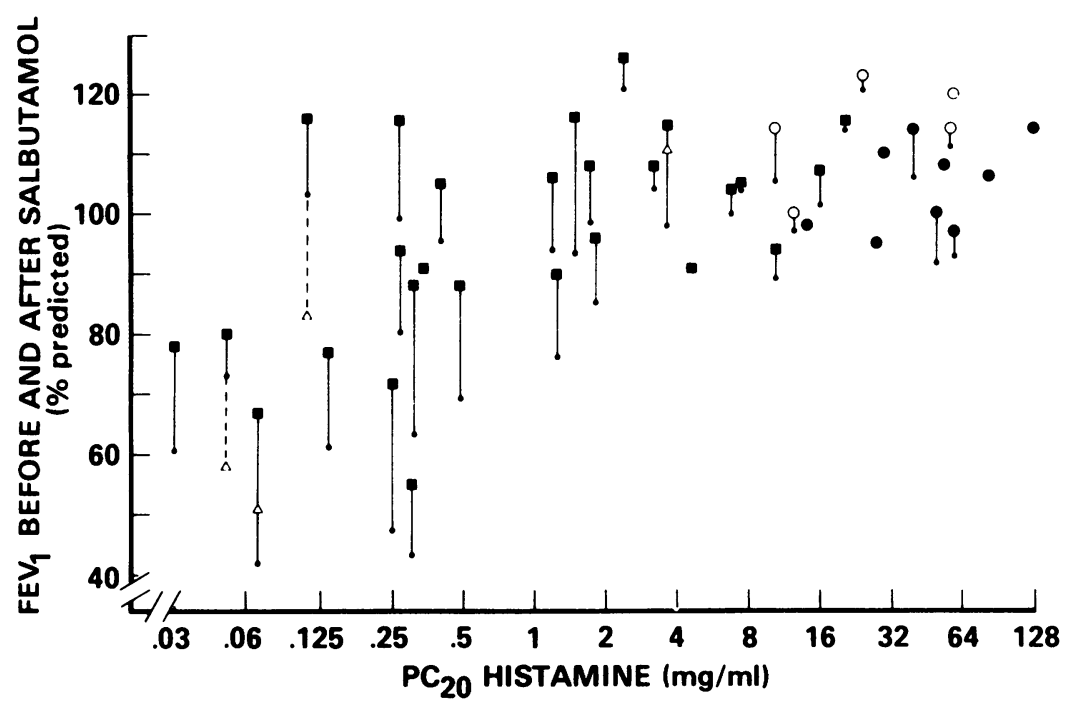

Fig 4 Relationship between $P C_{20}$ histamine $(\mathrm{mg} / \mathrm{ml})$ and $F E V_{1}$ as \% predicted, measured before $(\cdot)$ and 15 minutes after inhaled salbutamol $(200 \mu \mathrm{g})$.

(- nonasthmatics, O previous asthmatics, 1 current asthmatics). If the $F E V$, before salbutamol was more than $10 \%$ different from the $F E V$, before the histamine inhalation test the latter is also shown $(\nabla)$. When the difference was $<2 \%$ only one symbol is shown.

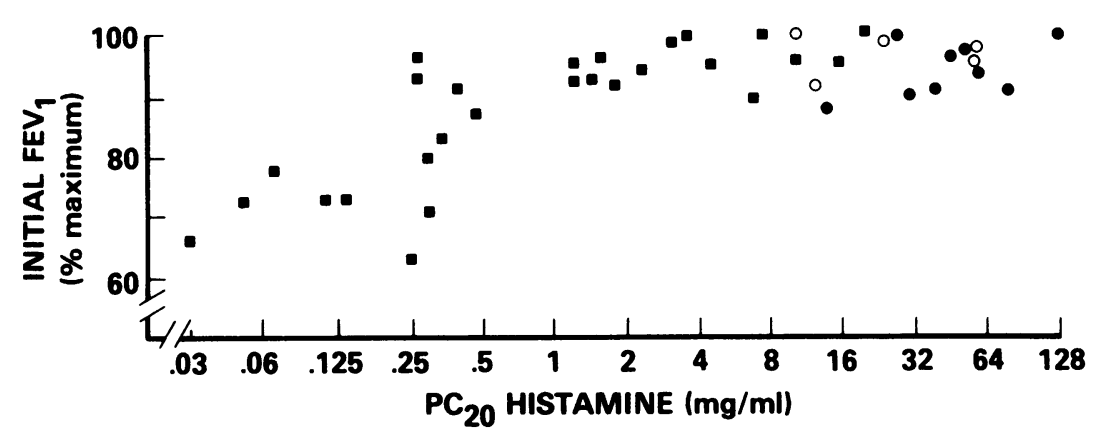

Fig 5 Relationship between $P_{20}$ histamine $(\mathrm{mg} / \mathrm{ml})$ and initial FEV at the time of the histamine inhalation test. FEV ${ }_{1}$ is expressed as a percentage of maximum FEV after inhaled salbutamol $(200 \mu \mathrm{g})$ measured seven days later. Symbols as in fig 1 .

smooth muscle of the sensitised dogs was more hyperresponsive to carbachol. ${ }^{25}$ It is therefore possible that bronchial responsiveness is the primary abnormality in asthma, which leads to the changes in smooth muscle tone and airway calibre.

Agreement has not been reached on the definition of asthma. Until there is more understanding of the causes and mechanisms of asthma a definition in terms of a disorder of function, such as that proposed by Scadding, ${ }^{1}$ is most satisfactory. However, as illustrated in the present study, an increase in the variability in airflow rates may be difficult to confirm in mild asthma without provocation challenge procedures. Fortunately increased nonspecific bronchial responsiveness is present in virtually all subjects with current symptoms of asthma and the responses to different nonspecific stimuli seem to correlate quite closely. ${ }^{910}$ Nonspecific responsiveness to histamine or methacholine can be easily measured" and normal responses to these agents and abnormal response to others such as exercise and cold air have not been observed.

The study was supported by grants from the Medical 
Research Council of Canada and from Schering Corporation Limited. We thank Robin Roberts for statistical advice and Dr NL Jones for reviewing the manuscript.

\section{References}

' Scadding JG. Definition and clinical categorisation. In: Weiss EB, Segal MS, eds. Bronchial asthma: mechanisms and therapeutics. Boston: Little, Brown and Company, 1976:1930.

${ }^{2}$ Ciba Foundation. Terminology, definitions and classification of chronic pulmonary emphysema and related conditions. Thorax 1959;14:286-92.

${ }^{3}$ American Thoracic Society. Definitions and classification of chronic bronchitis, asthma, and pulmonary emphysema. Am Rev Respir Dis 1962;85:762-8.

4 Pride NB. Practical use of pulmonary function tests. In: Clark TJH, Godfrey S, eds. Asthma. Philadelphia: Saunders, 1977:48-51.

${ }^{5}$ Hetzel MR, Clark TJH. Comparison of normal and asthinatic circadian rhythms in peak expiratory flow rate. Thorax 1980;35:732-8.

- Prior JG, Cochrane GM. Home monitoring of peak expiratory flow rate using mini-Wright peak flow meter in diagnosis of asthma. J R Soc Med 1980;73:731-3.

' Pepys J, Hutchcroft B. Bronchial provocation tests in etiological diagnosis and analysis of asthma. Am Rev Respir Dis 1975;112:829-59.

- Hargreave FE, Juniper EF, Ryan G et al. Clinical significance of nonspecific airway hyperreactivity. In: Hargreave FE, ed. Airway reactivity. Mississauga: Astra Pharmaceuticals Canada, 1980:216-21.

- Anderton RC, Cuff MT, Frith PA et al. Bronchial responsiveness to inhaled histamine and exercise. J Allergy Clin Immunol 1979;63:315-20.

${ }^{10}$ O'Byrne PM, Ryan G, Morris M et al. Asthma induced by cold air and its relation to nonspecific bronchial responsiveness to methacholine. Am Rev Respir Dis 1982;125:281-5.

" Cockcroft DW, Killian DN, Mellon JJA, Hargreave FE. Bronchial reactivity to inhaled histamine: a method and clinical survey. Clin Allergy 1977;7:235-43.
${ }^{12}$ Cherniack RM. Pulmonary function testing. Philadelphia: Saunders, 1977.

${ }^{13}$ Morris JF, Koski A, Johnson LC. Spirometric standards for healthy nonsmoking adults. Am Rev Respir Dis 1971;103:57-67.

${ }^{14}$ Cockcroft DW, Ruffin RE, Frith PA et al. Determinants of allergen-induced asthma: dose of allergen, circulating IgE antibody concentration and bronchial responsiveness to inhaled histamine. Am Rev Respir Dis 1979;120:1053-9.

${ }^{15}$ O'Brien IM, Newman-Taylor AJ, Burge PS, Harries MG, Fawcett IW, Pepys J. Toluene di-isocyanate-induced asthma. II Inhalation challenge tests and bronchial reactivity studies. Clin Allergy 1979;9:7-15.

${ }^{16}$ Cartier A, Frith PA, Roberts R, Thomson N, Hargreave FE Allergen-induced increase in bronchial responsiveness to histamine: relationship to the late asthmatic response and change in airway caliber. J Allergy Clin Immunol (in press).

${ }^{17}$ Lam S, Wong R, Yeung M. Nonspecific bronchial reactivity in occupational asthma. J Allergy Clin Immunol 1979;63:28-34.

${ }^{18}$ Empey DW, Laitinen LA, Jacobs L, Gold WM, Nadel JA. Mechanisms of bronchial hyperreactivity in normal subjects after upper respiratory tract infection. Am Rev Respir Dis 1976;113:131-9.

19 Rubinfeld AR, Pain MCF. Perception of asthma. Lancet 1976;1:882-4.

${ }^{20}$ Juniper EF, Frith PA, Hargreave FE. Airway responsiveness to histamine and methacholine: relationship to minimum treatment to control symptoms of asthma. Thorax 1981;36:57579.

${ }^{21}$ Department of Clinical Epidemiology and Biostatistics, McMaster University Health Sciences Centre. How to read clinical journals: II. To learn about a diagnostic test. Can Med Assoc J 1981;124:703-10.

${ }^{22}$ De Vries K, Goei JT, Booy-Noord H, Orie NGM. Changes during 24 hours in the lung function and histamine hyperreactivity of the bronchial tree in asthmatic and bronchitic patients. Int Arch Allergy 1962;20:93-101.

${ }^{23}$ Benson MK. Bronchial hyperreactivity. Br J Dis Chest 1975;69:227-39.

${ }^{24}$ Rubinfield AR, Pain MCF. Relationship between bronchial reactivity, airway calibre and severity of asthma. Am Rev Respir Dis 1977;115:381-7.

${ }^{25}$ Stephens NL, Mitchell RW, Antonissen LA et al. Airway smooth muscle: physical properties and metabolism. In: Hargreave FE, ed. Airway reactivity. Mississauga: Astra Pharmaceuticals Canada, 1980;110-31. 